\title{
Hypersensitivity in Dentistry
}

\author{
Shelly Lelyana ${ }^{1}$ \\ ${ }^{1}$ Department of Oral Medicine, Faculty of Dentistry, Maranatha Christian University- \\ Bandung, Indonesia \\ ${ }^{(*)}$ email: shelly.lelyana@gmail.com
}

\begin{abstract}
Immune system is a part of body defense system towards diseases, but the immune mechanism that normally defend the body could react in reverse or in other word could destroy its own body. This reaction is well known as hypersensitivity reaction. In dental practice, practitioners are using a few materials and several drugs to treat their patient, like metals, acrylics, antibiotics, hypnotics, anesthetics, to name a few. When using all kinds of dental materials and medication, dental practitioner should know how to handle the reaction that may possibly happened, most importantly in worst case scenario like patient hypersensitivity reaction the materials or medication. These hypersensitivity reaction usually manifests throughout the body and as a dental practitioner it is important to have an awareness on the signs and symptoms in the oral cavity, so practitioner could describe the cause and how to treat it. Dental practitioners should be aware on the materials and drugs that could be aware on the material and drugs that can be the potential allergens for the patient and the practitioner himself. The aim of this literature review is to give information on some of the most common hypersensitivity reaction in dentistry.
\end{abstract}

Keywords: Hypersensitivity, Allergy, Oral cavity 


\title{
Hipersensitivitas di Kedokteran Gigi
}

\begin{abstract}
Abstrak
Sistem imun merupakan bagian dari sistem pertahanan tubuh terhadap penyakit, namun mekanisme pertahanan tubuh yang secara normal dapat bereaksi secara terbalik atau dengan kata lain dapat merusak tubuhnya sendiri. Reaksi ini dikenal sebagai reaksi hipersensitivitas. Dalam praktik kedokteran gigi, praktisi menggunakan beberapa bahan dan beberapa obat untuk merawat pasiennya, seperti logam, akrilik, antibiotik, hipnotik, anestesi, dan lain-lain. Dalam menggunakan semua jenis bahan dan pengobatan gigi, praktisi gigi harus mengetahui cara menangani reaksi yang mungkin terjadi, terutama dalam skenario terburuk seperti reaksi hipersensitivitas pasien terhadap bahan atau obat tersebut. Reaksi hipersensitivitas ini biasanya bermanifestasi di seluruh tubuh dan sebagai praktisi gigi penting untuk memiliki kesadaran akan tanda dan gejala pada rongga mulut, sehingga praktisi dapat menjelaskan penyebab dan cara mengobatinya. Praktisi kedokteran gigi harus mewaspadai materi dan obat yang bisa diwaspadai pada materi dan obat yang bisa menjadi alergen potensial bagi pasien dan praktisi itu sendiri. Tujuan dari tinjauan pustaka ini adalah untuk memberikan informasi tentang beberapa reaksi hipersensitivitas yang paling sering terjadi dalam kedokteran gigi.
\end{abstract}

Kata kunci: Hipersensitivitas, Alergi, Rongga mulut 


\section{PENDAHULUAN}

Reaksi hipersensitivitas adalah reaksi abnormal dari sistem imun yang terjadi sebagai respon akibat terpapar dengan substansi yang membahayakan sehingga tingkat respon reaksinya bervariasi dari ringan sampai mematikan. Reaksi hipersensitivitas dapat mencakup kelainan autoimun dan alergi, seperti yang diketahui kondisi autoimun merupakan suatu respon imunologis abnormal yang menyerang bagian tubuhnya sendiri sedangkan alergi adalah respon imunologis abnormal yang timbul karena adanya stimulus dari lingkungan di luar tubuh (substansi eksogen). ${ }^{1,2}$

Reaksi hipersensitivitas terdiri dari beberapa tipe yaitu tipe 1 yang dimediasi oleh $\operatorname{IgE}$ (reaksi anafilaktik), tipe 2 yang dimediasi oleh antibodi, tipe 3 yang dimediasi oleh kompleks imun, dan tipe 4 yang dimediasi oleh sel (delayed hypersensitivity). Reaksi hipersensitivitas tipe 1 bersifat cepat dan akut seperti alergi terhadap penisilin, latex, kacang dan lainnya. Reaksi alergi ini dapat berdampak baik secara sistemik maupun lokal, dan reaksinya merupakan hasil ikatan silang antara antigen dan antibodi IgE yang berasal dari sel mast atau basofil. Mediator yang berperan pada saat reaksi anafilaktik antara lain histamin, serotonin, bradikinin, dan lipid sehingga berpotensi merusak jaringan. Reaksi hipersentivitas tipe 2 merupakan suatu reaksi sitotoksik, yang dimediasi oleh Immunoglobulin G (IgG) dan Immunoglobulin (IgM), antibodi bereaksi secara langsung terhadap antigen yang melekat pada membran sel sehingga menginduksi lisis pada sel, antigen ini dapat berasal dari instrinsik maupun ekstrinsik. Reaksi hipersensitivitas tipe 3 merupakan suatu reaksi kompleks imun contohnya seperti dapat terlihat pada infeksi virus herpes simpleks tipe 1 yang dapat berkembang menjadi eritema multiform. Pada reaksi hipersentivitias tipe $3, \operatorname{IgG}$ dan IgM yang berikatan dengan antigen akan membentuk kompleks antigen-antobodi sehingga akan menghasilkan polymorphonuclear neutrophilic leukocyte (PMN) yang akan mengeluarkan enzim perusak jaringan. Reaksi hipersensitivitas tipe 4 atau delayed hypersensitivity dimediasi sel atau kontak alergi, sering terjadi ketika berkontak dengan bahan di kedokteran gigi dan ditemukan pada rongga mulut dengan restorasi amalgam atau logam mulia yang berkontak dengan mukosa mulut. Reaksi dimediasi oleh sel $\mathrm{T}$ dan diinisiasi oleh sel T-limfosit. Respon ini akan membentuk interaksi dari antigen pada permukaan limfosit, sehingga limfosit akan memproduksi sitokin yang akan mempengaruhi fungsi dari sel lainnya. Reaksi ini terjadi 48-72 jam setelah kontak dengan antigen. ${ }^{1,3,4}$

Reaksi hipersensitivitas umumnya akan menimbulkan manifestasi pada tubuh sehingga sebagai praktisi wajib untuk mengetahui tanda dan gejala klinisnya dan mampu memberikan penanganan yang benar. Praktik di kedokteran gigi menggunakan berbagai bahan dental dan obat-obatan yang bervariasi seperti penggunaan antibiotik, hipnotik, dan anastetik. Ketika dokter gigi menggunakan medikasi maka harus mengetahui cara menangani reaksi hipersensitivitas yang mungkin dapat ditimbulkannya. ${ }^{1,5,6}$ Tinjauan ini akan membahas manifestasi klinis reaksi hipersensitivitas yang terjadi di rongga mulut serta penatalaksanaannya.

\section{STUDI PUSTAKA}

\section{Urtiklaria dan Angioedema}

Reaksi anafilaktik (hipersensitivitas tipe 1 terjadi secara lokal pada pembuluh darah superfisial dan menghasilkan urtikaria. Urtikaria merupakan suatu kondisi kelainan kulit berupa reaksi vaskular yang terjadi karena pruritus atau gatal pada daerah yang kontak dengan alergen, kemudian akan muncul welt atau tanda merah pada daerah mukosa atau kulit tersebut. Angioedema merupakan reaksi dengan gambaran klinis pembengkakan dengan konsistensi lunak, tidak gatal dan sakit serta dapat terjadi secara cepat setelah berkontak 
dengan allergen. Hal ini umum terjadi pada kepala dan leher. Terkadang angioedema dan urtikaria dapat terjadi pada daerah yang sama. ${ }^{3,5,6}$

Urtikaria pada bibir dan mukosa mulut sering terjadi setelah menelan makanan yang menimbulkan alergi pada individu tertentu, seperti coklat, kacang, kerang, dan tomat. Obat seperti penisilin dan aspirin dapat menyebabkan urtikaria, dan pada bidang kedokteran gigi bahan cetak, bahan perwarna, bahan pengawet dan bahan-bahan pada obat kumur dapat menyebabkan pembengkakan lokal ataupun anafilaksis. Angiodema paling umum terjadi pada bibir, lidah dan disekitar mata, yang disebabkan baik oleh obat-obatan maupun makanan. $5,6,7$

Urtikaria dan angioedema hanya bersifat sementara. Kondisi ini akan menimbulkan masalah jika oedema terjadi pada daerah posterior lidah atau laring karena gangguan pada saluran pernapasan. Penanganan kondisi tersebut adalah dengan injeksi epinefrin secara intramuskuler sebanyak $0.5 \mathrm{~mL}(1: 1000)$ yang diulang 10 menit sekali dan pemberian oksigen jika masih terdapat pembengkakan.,

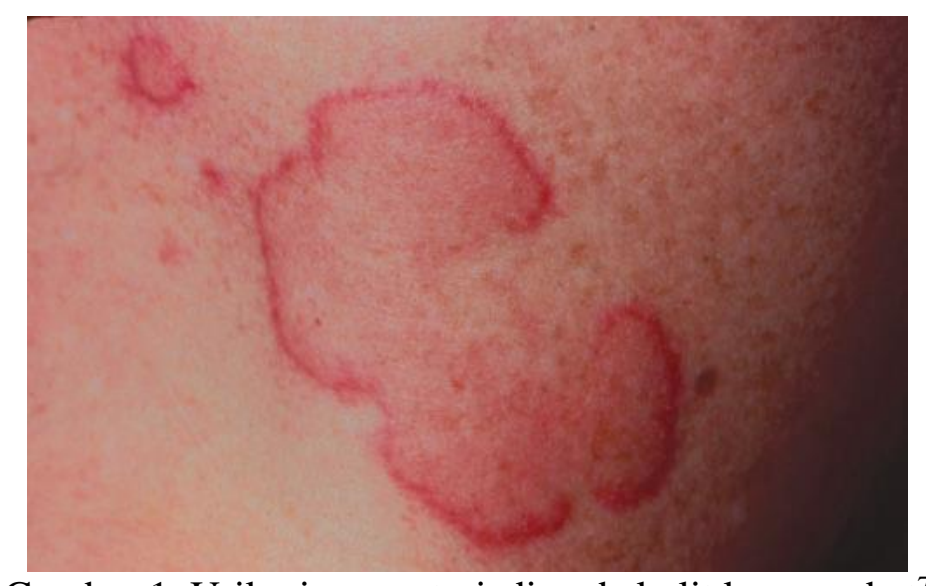

Gambar 1. Urikaria yang terjadi pada kulit karena obat ${ }^{7}$

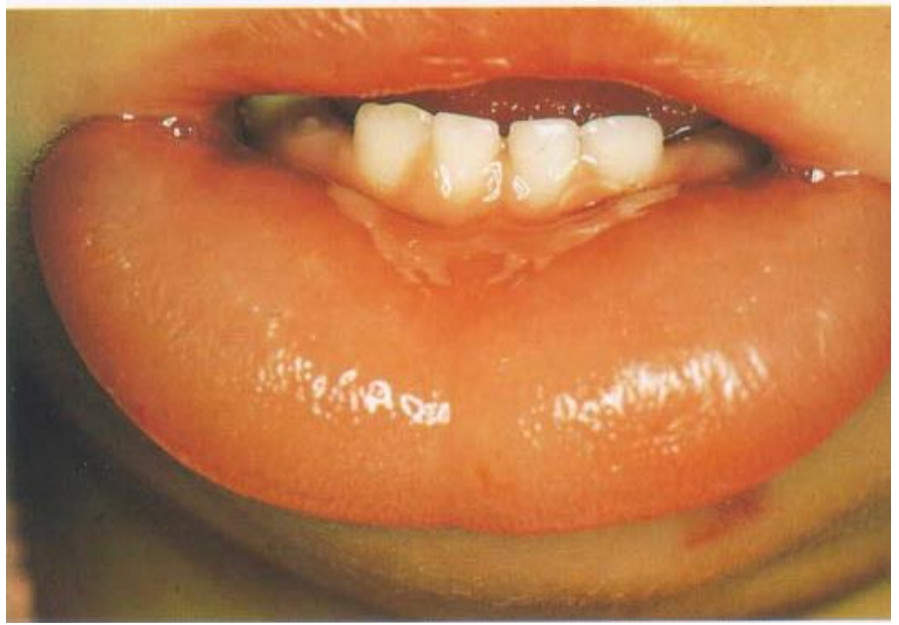

Gambar 2. Angioedema pada bibir ${ }^{8}$

\section{Eritema Multiforme}

Eritema multiforme merupakan suatu penyakit kulit akut, self-limited, dan dapat berulang yang berkaitan dengan reaksi hipersensitivitas. Kondisi ini terjadi karena reaksi hipersensitivitas kompleks imun (tipe 3) yang terjadi 7-10 hari setelah alergen masuk dan 
antibodi IgG yang terbentuk akan berikatan dengan antigen dari alergen tersebut sehingga menimbulkan inflamasi bahkan ulserasi. Reaksi hipersensitivitas ini dapat disebabkan oleh infeksi virus dan obat seperti NSAIDs, sulfonamides, antikonvulsan, phenitonin juga dapat menimbulkan kondisi ini. ${ }^{1,9}$

Eritema multiforme dapat timbul di kulit dan rongga mulut yang dimulai dengan adanya pembengkakan dan eritema, kemudian terjadi pembentukan blister atau lepuhan yang pecah dan meninggalkan daerah ulserasi. Pada beberapa kasus, bibir menjadi bengkak dan timbul krusta atau kerak yang menimbulkan pendarahan, dan pada kulit secara khas ditandai dengan adanya lesi target atau iris lesion yang pada umumnya muncul di daerah tangan, kaki dan permukaan ekstensor dari siku dan lutut. ${ }^{7,9,10}$

Eritema multiforme di rongga mulut yang ringan dapat di rawat dengan perawatan suportif seperti obat kumur anestesi topikal dan makan-makanan yang lunak. Pada kasus dengan lesi yang luas dan lebih berat dapat diatasi dengan kortikosteroid sistemik jangka pendek kecuali pada pasien dengan kontraindikasi pengunaan steroid. ${ }^{1,10}$

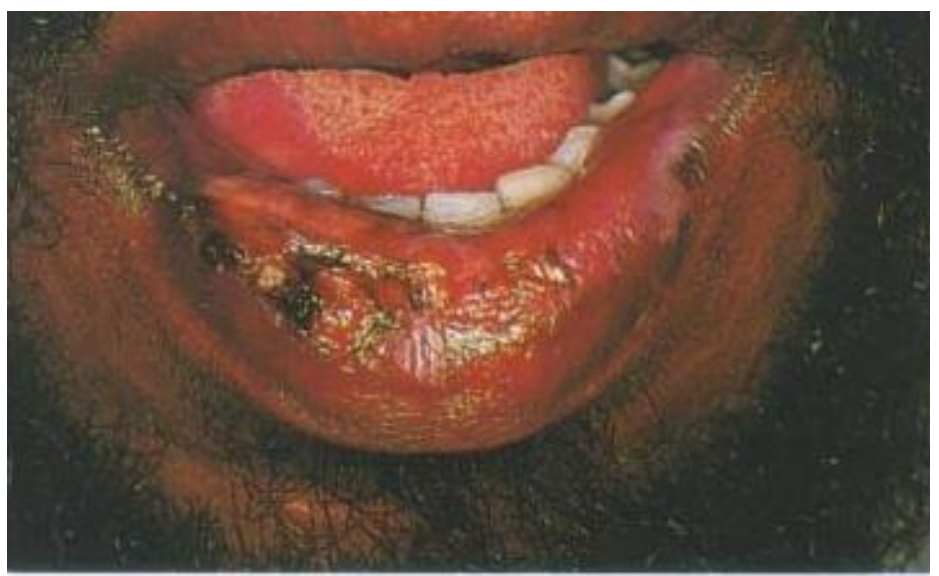

Gambar 3. Eritema multiform pada bibir yang bengkak dan terdapat krusta ${ }^{8}$

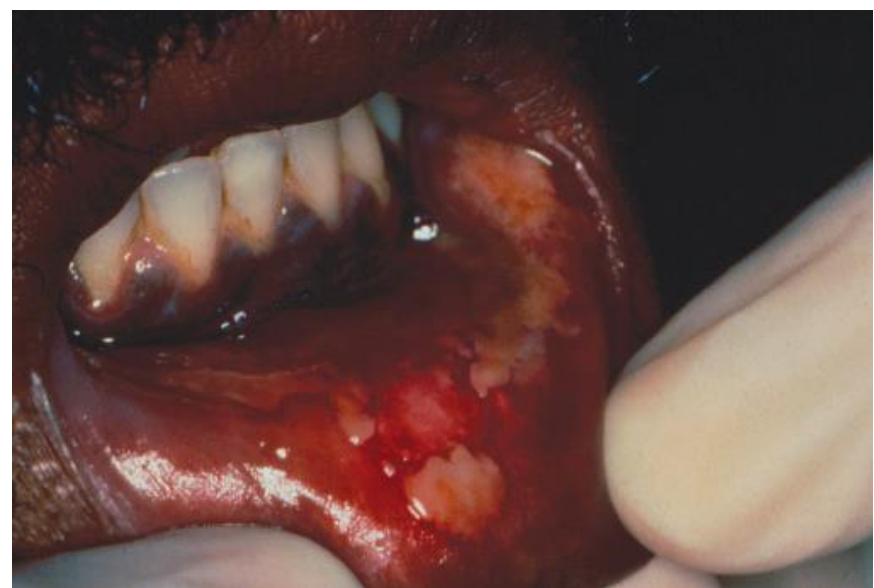

Gambar 4. Eritema multiform pada mukosa bibir, terdapat lepuh yang pecah menjadi ulser ${ }^{7}$ 


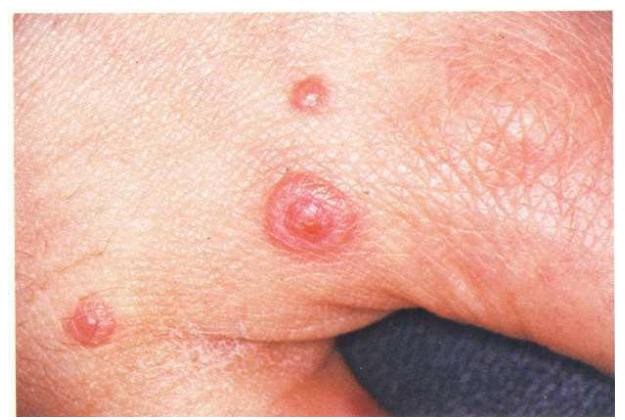

Gambar 5. Lesi target atau iris lesion pada kulit yang menjadi ciri khas eritema multiform ${ }^{11}$

\section{Contact Allergic Stomatitis}

Contact allergic stomatitis merupakan hasil dari reaksi hipersensitivitas tipe 4 (delayed hypersensitivity) yang terjadi ketika antigen memasuki jaringan sehingga mengaktifkan sel langerhans dan akan berinteraksi dengan limfosit $\mathrm{T}$ sehingga menimbulkan reaksi inflamasi pada lokasi kontak. Gambaran klinis contact allergic stomatitis ditandai dengan adanya eritema dan pembengkakan yang dapat terjadi di seluruh daerah di rongga mulut, baik lidah, palatum, mukosa, dan bibir. ${ }^{1,12}$

Contact allergic stomatitis dapat diakibatkan oleh kontak dengan bahan yang digunakan di kedokteran gigi, produk-produk yang digunakan untuk menjaga kebersihan rongga mulut, ataupun oleh makanan. Penyebab yang paling umum adalah kayu manis dan mint, sering digunakan sebagai bahan perasa di makanan, permen, dan permen karet, serta produk untuk menjaga kebersihan rongga mulut seperti pasta gigi, obat kumur, dan benang gigi. Bahan di bidang kedokteran gigi yang menyebabkan reaksi tipe ini antara lain adalah merkuri pada amalgam, logam mulia pada mahkota, monomer bebas yang dikandung di dalam akrilik, nikel pada kawat ortodontik atau gigi tiruan, serta bahan logam pada implan. ${ }^{7,12,13}$

Tanda dan gejala klinis dari contact allergic stomatitis di rongga mulut tidak spesifik dan umumnya sulit dibedakan dengan iritasi secara fisik. Reaksi yang terjadi pada daerah kontak adalah rasa terbakar atau rasa perih yang disertai eritema, dan terkadang terbentuk vesikel dan ulser. Lesi lichenoid dengan gambaran klinis garis plak putih tidak beraturan pada mukosa bukal dan tepi lateral lidah yang berkontak langsung dengan amalgam. Gingivitis juga dapat menjadi tanda terjadinya contact allergic stomatitis dengan gambaran klinis terdapat eritema dan edema secara menyeluruh pada gingiva cekat dan terkadang diikuti dengan terdapatnya cheilitis dan glositis. Hal ini dapat terjadi pada beberapa kasus yang dipicu oleh penggunaan pasta gigi, permen karet atau permen. Contact allergic stomatitis dapat secara pasti terdiagnosis jika terjadi inflamasi pada daerah yang dilakukan patch test dengan meletakan alergen pada kulit selama 48 jam. ${ }^{1,12,13}$ Penatalaksanaan kasus contact allergic stomatitis ringan cukup dengan menghilangkan penyebab (allergen) dari permukaan yang terkena. Pada kasus yang berat dan menimbulkan keluhan nyeri maka dapat menggunakan steroid secara topikal untuk mempercepat penyembuhan dan menghilangkan rasa sakit. ${ }^{1,13}$ 


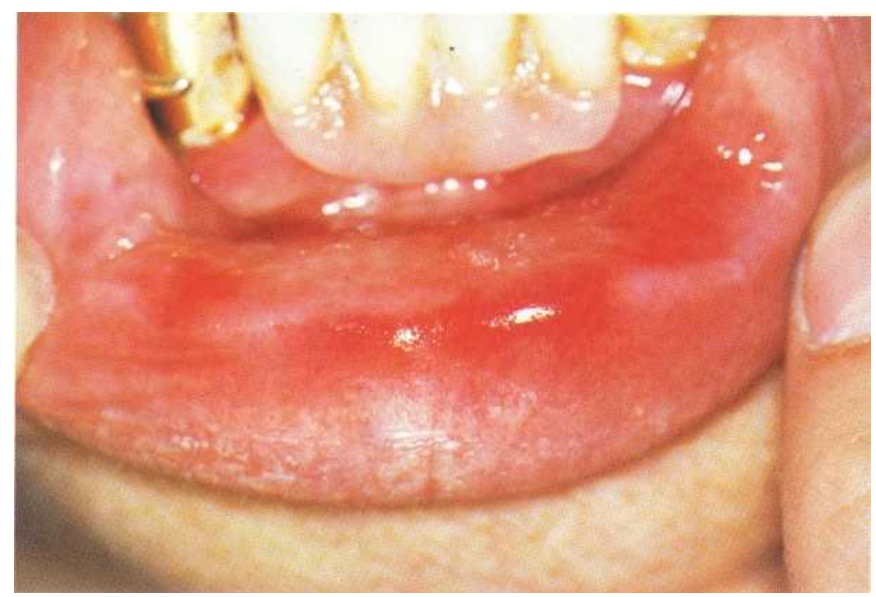

Gambar 6. Stomatitis akibat kontak alergi dengan resin akrilik ${ }^{8}$

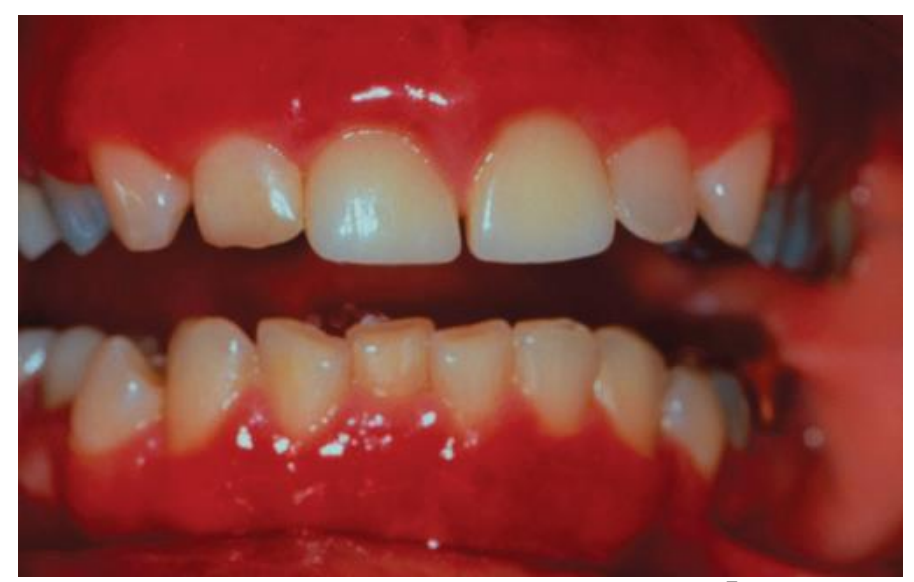

Gambar 7. Gingivitis plasma sel ${ }^{7}$

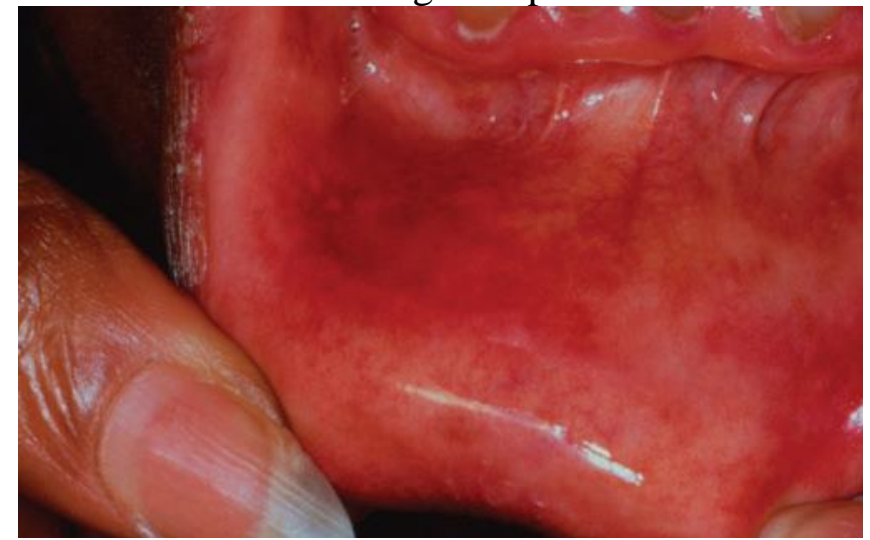

Gambar 8. Kontak alergi terhadap peppermint pada mukosa labial ${ }^{7}$

\section{Oral Lichenoid Reaction}

Oral lichenoid reaction (OLR) adalah reaksi hipersensitivitas tipe 4 (delayed hypersensitivity). Kondisi ini berkaitan dengan imunitas sel terhadap antigen yang terdapat pada obat-obatan, bahan perasa makanan, dan bahan restorasi di bidang kedokteran gigi seperti tambalan amalgam, logam mulia, komposit, ataupun glass ionomer. ${ }^{1}$ Secara klinis OLR terlihat sebagai garis-garis plak berwarna putih yang terkadang disertai daerah berwarna merah, bersifat kronis, posisi unilateral, permukaan lesi sedikit timbul, tipis, dan umumnya terletak di mukosa bukal dekat dengan restorasi penyebab lesi ini. ${ }^{7,8}$

Oral lichenoid reaction perlu diperhatikan karena pada beberapa penelitian lesi ini memiliki potensi untuk menjadi ganas. Jika lesi muncul di rongga mulut dan kulit maka 
riwayat pemakaian obat merupakan aspek yang perlu ditelaah karena kemungkinan besar penyebabnya berasal dari obat yang dikonsumsi pasien sehingga perlu penatalaksanaan secara holistik dengan sejawat medis lainnya untuk menghentikan atau mengubah obat tersebut. Pada umumnya lesi akan hilang dalam beberapa bulan jika penyebab dihilangkan. Jika OLR disebabkan oleh restorasi di rongga mulut, maka restorasi dapat diganti dengan bahan lainnya. ${ }^{7,14}$

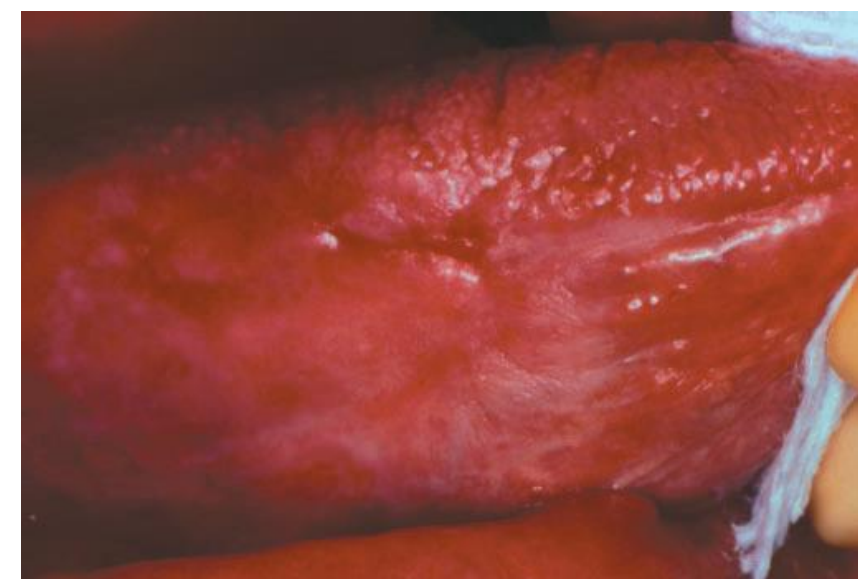

Gambar 9. Lesi lichenoid karena obat-obatan yang berupa plak berwarna merah-keputihan pada sisi lateral lidah ${ }^{7}$

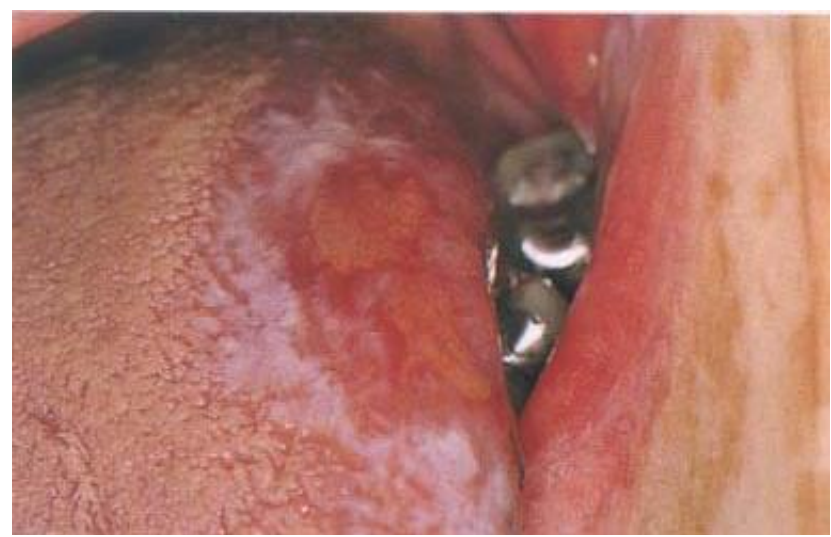

Gambar 10. Lesi lichenoid pada lidah akibat restorasi logam ${ }^{11}$

\section{Serum Sickness}

Serum sickness dimediasi kompleks imun (hipersensitivitas tipe 3) yang terjadi karena pemberian serum untuk perawatan terhadap infeksi penyakit. Reaksi ini dapat ditemukan pada pemeberian antitoxin tetanus, antiserum rabies, dan obat yang berkombinasi dengan badan protein dan membentuk alergen. Serum sickness umumnya terjadi 7-10 hari setelah kontak dengan alergen, dan jangka waktunya bervariasi dari 3 hari sampai dengan selama 1 bulan. ${ }^{1}$

Gejala utama serum sickness berupa demam, pembengkakan, limfadenopati, nyeri sendi dan otot, dan gatal. Pada beberapa penelitian, serum sickness di bidang kedokteran gigi dapat terjadi akibat pemberian obat dengan golongan penisilin. ${ }^{15,16}$ Serum sickness merupakan kondisi yang akan hilang dengan sendirinya (self-limiting). Kondisi ini terjadi spontan dan sembuh setelah 1-3 minggu. Pengobatan kondisi nyeri sendi dapat diberikan aspirin sedangkan rasa gatal dapat dihilangkan dengan penggunaan antihistamin. ${ }^{7}$ 


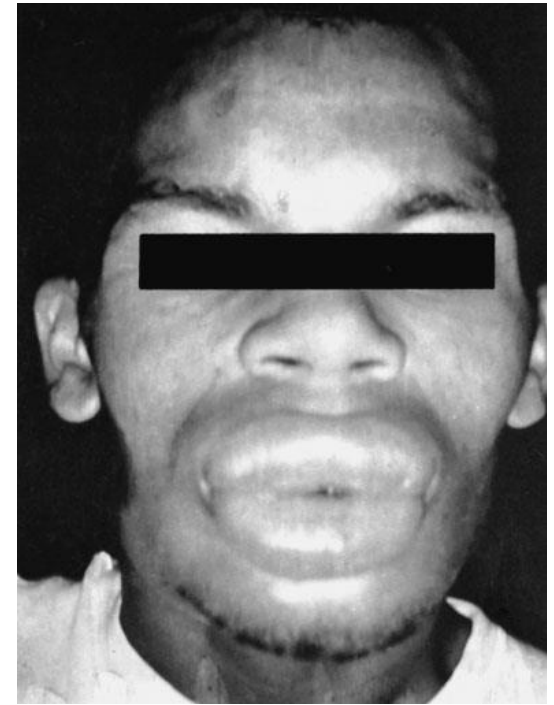

Gambar 11. Edema pada bibir akibat reaksi alergi terhadap penisilin ${ }^{7}$

\section{Alergi terhadap lateks}

Kasus alergi terhadap lateks telah meningkat seiring dengan waktu dimana reaksi hipersensitivitas yang terjadi secara langsung saat lateks berkontak dengan kulit maupun mukosa. ${ }^{1,17}$ Individu dengan alergi lateks dapat menunjukkan respon berupa urtikaria, rhinitis, dan edema kelopak mata, dan pada kasus yang berat dapat menimbulkan reaksi sistemik seperti asma dan anafilaksis. ${ }^{1}$

Manajemen dari permasalahan berupa penanganan pasien ataupun tenaga medis yang alergi terhadap lateks dengan cara preventif. Evaluasi awal perlu dilakukan dan perlu di catat di dalam rekam medis jika pasien dan atau tenaga medis alergi terhadap lateks sehingga pada perawatan selanjutnya penggunaan bahan seperti lateks dapat dihindari. Pekerja di bidang medis dapat menghindari penggunaan lateks dengan cara mengganti sarung tangan yang umumnya berbahan lateks dengan bahan alternatif lain. Reaksi sistemik akut yang mungkin terjadi harus ditanggulangi dengan protokol penilaian jalur nafas dan sirkulasi, pemberian oksigen, administrasi epinefrin dan steroid jika diperlukan. ${ }^{1,17,18}$

\section{SIMPULAN}

Praktisi di bidang kedokteran gigi perlu berhati-hati karena tidak sedikit benda yang dipakai pada praktik sehari-hari berpotensi sebagai allergen yang dapat merugikan pasien maupun diri sendiri. Praktisi di kedokteran gigi perlu mengetahui tanda dan gejala reaksi hipersensitivitas selain kemampuan anamnesis sebaik mungkin sehingga jika terjadi kondisi tersebut maka dokter gigi diharapkan mampu menjelaskan kepada pasien dan menerapkan manajemen penanggulangannya secara tepat. 


\section{DAFTAR PUSTAKA}

1. Michael G. Burket's Oral Medicine 12 ${ }^{\text {th }}$ Edition. PMPH. 2014.

2. Kumar V, Abbas AK, Aster JC. Robbins \& Cotran pathologic Basis of Disease. Elsevier Saunders. 2015.

3. Axell T. Hypersensitivity of the oral mucosa: clinics and pathology. Acta Odontol Scand. 2001. Oct;59(5):315-9.

4. Roland S, David AK. Drug Allergy: An Updated Practice Parameter. ANNALS. 2010. 105(4):259-273.

5. Gregory MC, Richard FL. Oral Manifestations of Allergic, Infectious, and Immunemediated Disease. The Journal of Allergy and Clinical Immunology: In Practice. 2010.125(3) 569-74.

6. Paola LM, Giovanni P, Maddalena V. Unmet diagnostic needs in contact oral mucosal allergies. Clinical and Molecular Allergy. 2016.14(1):10.

7. Martin SG, Michael G. Burket's Oral Medicine 10 $0^{\text {th }}$ Edition. BC Decker Inc. 2003.

8. Crispian S. Handbook of Oral Disease: Diagnosis and Management. Martin Dunitz. 1999.

9. Parvinderjit SK, Jasbir K. Eythema Multiforme-Oral Variant: Case Report and Review of Literature. Indian J Otolaryngol Head Neck Surg. 2011. 63(1):9-12

10. Rafael LVO, Reneta GMB, Isabela AP. Management of Eritema multiforme Associated with Recurrent Herpes Infection: A Case Report. JCDA. 2009. 75(8).597-601.

11. Langlais R., Miller C. Color Atlas of Common Oral Diseases, 5th Edition.Jones and Bartlett Learning.2017

12. Tosti A, Piraccini BM, Pazzaglia M. Contact Stomatitis. Semin Cutan Med Surg. 1997 Dec. 16(4):314-9.

13. Torgerson RR, Davis MD, Bruce AJ. Contact Allergy in Oral Disease.J Am Acad Dermatol. 2007; 57(2):315-21

14. Baris E, Senguven B, Tuzuner T. Oral Lichenoid Lesions Related to Drugs: Review of Clinicopathological Features and Differential Diagnosis. Sage Journal. 2014; 12(2):217225

15. Clark BM, Kotti GH, Shah AD. Severe serum sickness reaction to oral and intramuscular penicillin. Pharmacotherapy. 2006. 26(5):705-8.

16. Ashley JT, Anne MD, Roy P. Severe serum sickness-like reaction to oral penicillin drugs: three case reports. ANNALS. 2001;86(3).330-334

17. Pollard RJ, Layon Aj. Latex allergy in the operating room: case report and a brief review of literature. J CLin Anesth. 1996; 8:161-167.

18. Daniela PR, Lucila BC, Giselle MCCN. Latex allergy in dentistry: clinical cases report. J Clin Exp Dent. 2010;2(1):55-9. 